\title{
NUMERICAL CALCULATIONS OF WR-40 BOILER BASED ON ITS ZERO-DIMENSIONAL MODEL
}

\author{
Bartłomiej Hernik* $^{*}$ \\ Silesian University of Technology in Gliwice, Institute of Power Engineering and Turbomachinery, \\ ul. Konarskiego 18, 44-100 Gliwice, Poland
}

\begin{abstract}
Generally, the temperature of flue gases at the furnace outlet is not measured. Therefore, a special computation procedure is needed to determine it. This paper presents a method for coordination of the numerical model of a pulverised fuel boiler furnace chamber with the measuring data in a situation when CFD calculations are made in regard to the furnace only. This paper recommends the use of the classical 0-dimensional balance model of a boiler, based on the use of measuring data. The average temperature of flue gases at the furnace outlet $t_{k}^{\prime \prime}$ obtained using the model may be considered as highly reliable. The numerical model has to show the same value of $t_{k}^{\prime \prime}$. This paper presents calculations for WR-40 boiler. The CFD model was matched to the 0 -dimensional $t_{k}^{\prime \prime}$ value by means of a selection of the furnace wall emissivity. As a result of CFD modelling, the flue gas temperature and the concentration of $\mathrm{CO}, \mathrm{CO}_{2}, \mathrm{O}_{2}$ and $\mathrm{NO}_{\mathrm{x}}$ were obtained at the furnace chamber outlet. The results of numerical modelling of boiler combustion based on volumetric reactions and using the Finite-Rate/Eddy-Dissipation Model are presented.
\end{abstract}

Keywords: CFD modelling, boilers, combustion, grate

\section{INTRODUCTION}

CFD modelling of power boiler furnace chambers is often performed in the engineering practice (Asotani et al., 2008; Dal-Secco et al., 2007; Hernik, 2012). Quite often, however, balance calculations are not carried out for the entire boiler. In consequence, the flue gas temperature at the furnace outlet $t_{k}^{\prime \prime}$ in a CFD model results from assumptions made (e.g. wall fouling or emissivity). Therefore, the $t_{k}^{\prime \prime}$ value may be wrong, and the presented calculation method makes it impossible to verify it. Using a fully-balanced 0 -dimensional model, it is possible to verify the $t_{k}^{\prime \prime}$ value obtained from numerical calculations. Numerical calculations should be carried out in such a way that the average temperature at the furnace chamber outlet in the CFD model equals that obtained from the zero-dimensional model. At the same time, the matching of this temperature should result from carefully selected assumptions of the numerical model, which have to correspond to the actual phenomena occurring in the furnace. This paper presents the verification of the CFD model for the WR-40 boiler. The WR-40 boiler is a twopass, radiant, stoker-fired boiler fed with hard coal. Primary air is supplied from below the stoker and secondary air I and II is fed by a set of nozzles over the furnace ignition arch. The furnace has 9096 $\mathrm{mm}$ height and the dimensions of the grate are $6440 \times 6770 \mathrm{~mm}$.

*Corresponding author, e-mail: bartlomiej.hernik@polsl.pl 


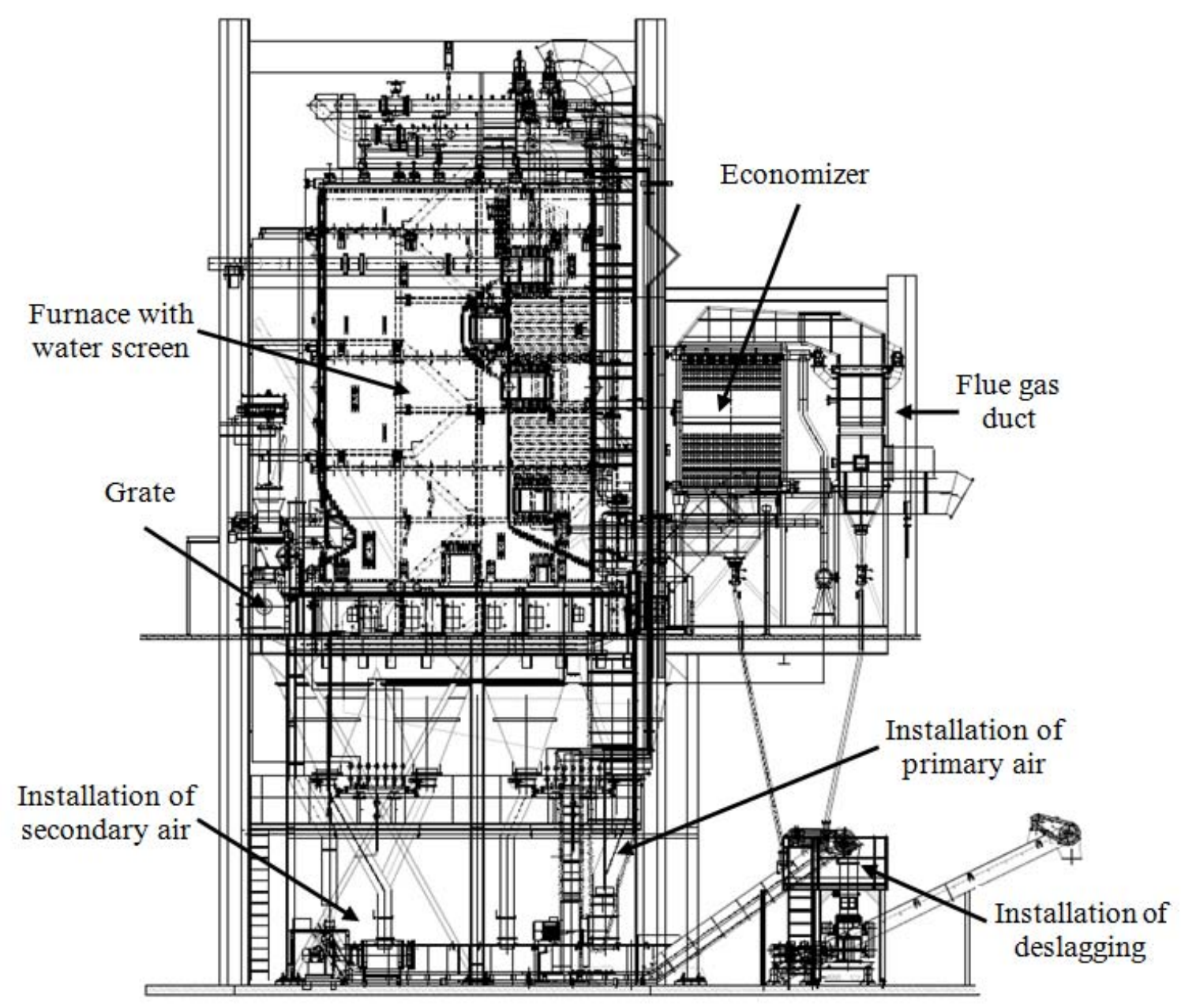

Fig. 1. Contour of the WR-40 boiler

\section{BOILER CALCULATIONS USING THE ZERO-DIMENSIONAL MODEL}

The calculation methodology is presented elsewhere (Hernik and Pronobis, 2012a; Hernik and Pronobis, 2012b). The calculations were made for data listed in Tables 1 and 2.

Table 1. The boiler operating parameters

\begin{tabular}{|l|c|c|}
\hline \multicolumn{1}{|c|}{ Data } & Unit & Value \\
\hline Coal mass flow & $\mathrm{kg} / \mathrm{s}$ & 2.22 \\
\hline Primary air mass flow & $\mathrm{kg} / \mathrm{s}$ & 5.35 \\
\hline Secondary air I mass flow & $\mathrm{kg} / \mathrm{s}$ & 2.59 \\
\hline Secondary air II mass flow & $\mathrm{kg} / \mathrm{s}$ & 2.59 \\
\hline Primary air temperature & ${ }^{\circ} \mathrm{C}$ & 150 \\
\hline Secondary air temperature & ${ }^{\circ} \mathrm{C}$ & 80.00 \\
\hline
\end{tabular}

Table 2. Coal analysis (as-received state)

\begin{tabular}{|c|c|c|c|c|c|c|c|}
\hline$Q^{\mathrm{r}}{ }_{\mathrm{i}}$ & $A^{\mathrm{r}}$ & $W_{\mathrm{t}}^{\mathrm{r}}$ & $\mathrm{C}^{\mathrm{r}}$ & $\mathrm{H}^{\mathrm{r}}$ & $\mathrm{S}^{\mathrm{r}}$ & $\mathrm{O}^{\mathrm{r}}$ & $\mathrm{N}^{\mathrm{r}}$ \\
\hline $\mathrm{kJ} / \mathrm{kg}$ & $\%$ & $\%$ & $\%$ & $\%$ & $\%$ & $\%$ & $\%$ \\
\hline 22114 & 21.5 & 11.2 & 57 & 3.9 & 1.1 & 4.8 & 0.6 \\
\hline
\end{tabular}




\section{MODELLING DESCRIPTION AND BOUNDARY CONDITIONS}

The modelling input data implemented into the Fluent.Inc code are presented above in Tables 1 and 2 . The contour of the furnace chamber of the numerical model of the WR-40 boiler is shown in Fig. 2 . The geometrical model and the numerical mesh composed of 668953 numerical cells are presented in Fig. 3. The steady state governing equations were solved using the SIMPLE algorithm (Eaton et al. 1999; Kær et al. 2006; Scharler et al. 2000). As defined in the model, combustion in the boiler occurs according to volumetric reaction using the Finite-Rate/Eddy-Dissipation Model. Table 4 presents the numerical model assumptions. Below, the reaction of the mechanism of the volatile fraction combustion is presented ( $m, n, l, k$ - based on coal composition). Coal is fed onto the stoker and fired. Combustion of the volatiles was simplistically represented by two overall reactions:

$$
\begin{gathered}
\mathrm{C}_{\mathrm{m}} \mathrm{H}_{\mathrm{n}} \mathrm{O}_{1} \mathrm{~N}_{k}+\left(\frac{m-l}{2}+\frac{n}{4}\right) \mathrm{O}_{2} \stackrel{k_{1}}{\longrightarrow} m \mathrm{CO}+\frac{n}{2} \mathrm{H}_{2} \mathrm{O}+\frac{k}{2} \mathrm{~N}_{2} \\
\mathrm{CO}+0.5 \mathrm{O}_{2} \stackrel{k_{2}}{\longrightarrow} \mathrm{CO}_{2}
\end{gathered}
$$

\begin{tabular}{|c|c|c|}
\hline Two-phase model & \multicolumn{2}{|c|}{ Euler- Lagrange (Eaton et al., 1999; He et al. 2007; Scharler et al., 2000) } \\
\hline Turbulence model & \multicolumn{2}{|c|}{$k-\varepsilon$ real (Yin et al., 2008; Scharler et al., 2000) } \\
\hline \multirow{5}{*}{ Combustion model } & \multicolumn{2}{|c|}{$\begin{array}{l}\text { Finite-Rate/Eddy-Dissipation Model (Yin et al., 2008; Scharler et al., 2000; Kær } \\
\text { et al., 2006) }\end{array}$} \\
\hline & Reaction $k_{1}$ & Reaction $k_{2}$ \\
\hline & $A=2.119 \mathrm{e}+11$ & $A=2.239 \mathrm{e}+12$ \\
\hline & $E=2.027 \mathrm{e}+8 \mathrm{~J} / \mathrm{kmol}$ & $E=1.7 \mathrm{e}+8 \mathrm{~J} / \mathrm{kmol}$ \\
\hline & \multicolumn{2}{|c|}{$\begin{array}{l}\text { Flue gas absorptivity: wsggm-domain-based model, calculates absorptivity based } \\
\text { on the concentration of } \mathrm{CO}_{2} \text { and } \mathrm{H}_{2} \mathrm{O} \text { (Eaton et al., 1999; Kær et al., 2006) }\end{array}$} \\
\hline \multicolumn{3}{|c|}{ For a coal particle } \\
\hline \multirow{3}{*}{ - devolatilisation } & \multicolumn{2}{|c|}{ Single-rate model } \\
\hline & \multicolumn{2}{|c|}{$A=382000$} \\
\hline & \multicolumn{2}{|c|}{$E=7.4 \mathrm{e}+7 \mathrm{~J} / \mathrm{kmol}$} \\
\hline \multirow{4}{*}{ - combustion } & \multicolumn{2}{|c|}{ Kinetic-diffusion model (Williams A. et al. 2002) } \\
\hline & \multicolumn{2}{|c|}{$C 1=5 \mathrm{e}+12$} \\
\hline & \multicolumn{2}{|c|}{$C 2=0.002$} \\
\hline & \multicolumn{2}{|c|}{$E A=7.9 \mathrm{e}+7 \mathrm{~J} / \mathrm{kmol}$} \\
\hline Radiation model & \multicolumn{2}{|c|}{ DO (Yin et al., 2008; Scharler et al., 2000; Kær et al., 2006) } \\
\hline \multicolumn{3}{|c|}{$\mathrm{NO}_{\mathrm{x}}$ model } \\
\hline formation & \multicolumn{2}{|c|}{ thermal and fuel pathways } \\
\hline concentration of $\mathrm{OH}$ and $\mathrm{O}$ & \multicolumn{2}{|c|}{ partial equilibrium } \\
\hline turbulence interaction & \multicolumn{2}{|c|}{ temperature mode } \\
\hline $\mathrm{N}$ intermediate & \multicolumn{2}{|c|}{$\mathrm{HCN} / \mathrm{NH}_{3} / \mathrm{NO}$} \\
\hline Char N conversion & \multicolumn{2}{|c|}{ NO } \\
\hline
\end{tabular}

Table 3. Assumptions of the numerical model (Ansys.Fluent) 


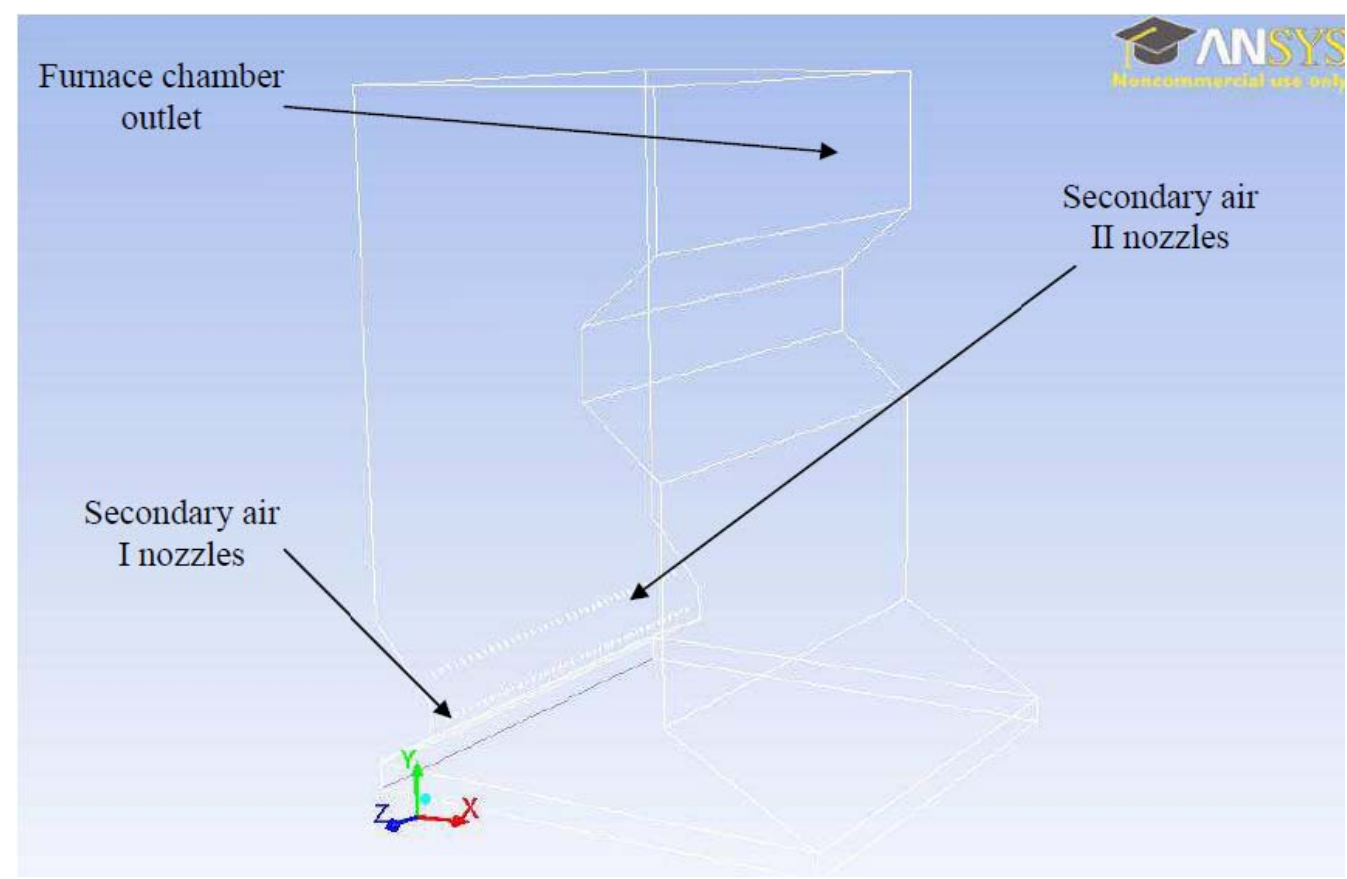

Fig. 2. Drawing of the WR-40 boiler furnace chamber

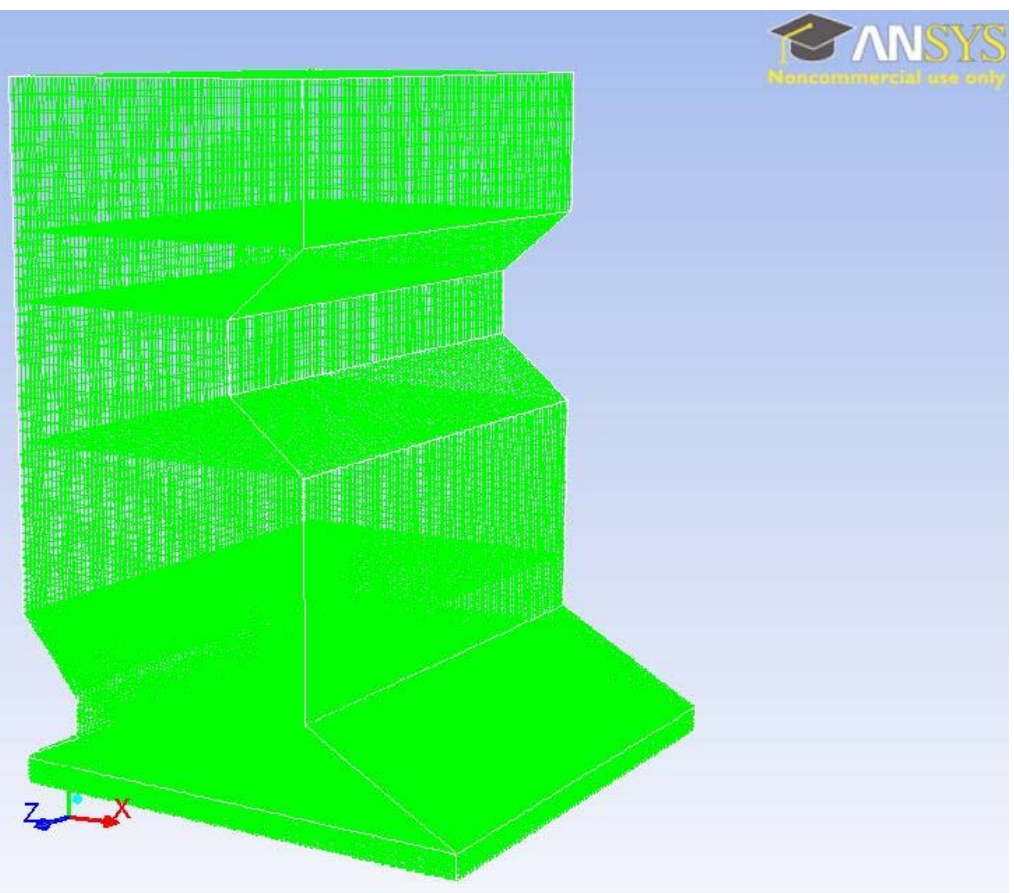

Fig. 3. Numerical mesh of the WR-40 boiler furnace chamber

\section{RESULTS OF NUMERICAL MODELLING}

Fig. 4 presents the content of $\mathrm{O}_{2}$ in the central planes, over the stoker and in the outlet window plane. The content of $\mathrm{O}_{2}$ depending on combustion process of coal on the grate and volatiles over the grate along the height of the furnace.

Fig. 5 presents the content of $\mathrm{CO}$ in the central planes, over the stoker and in the outlet window plane. $\mathrm{CO}$ content appears in region of devolatilisation of coal on the grate and as a result of combustion of volatiles. Along the height of the furnace $\mathrm{CO}$ was oxidised to $\mathrm{CO}_{2}$. 


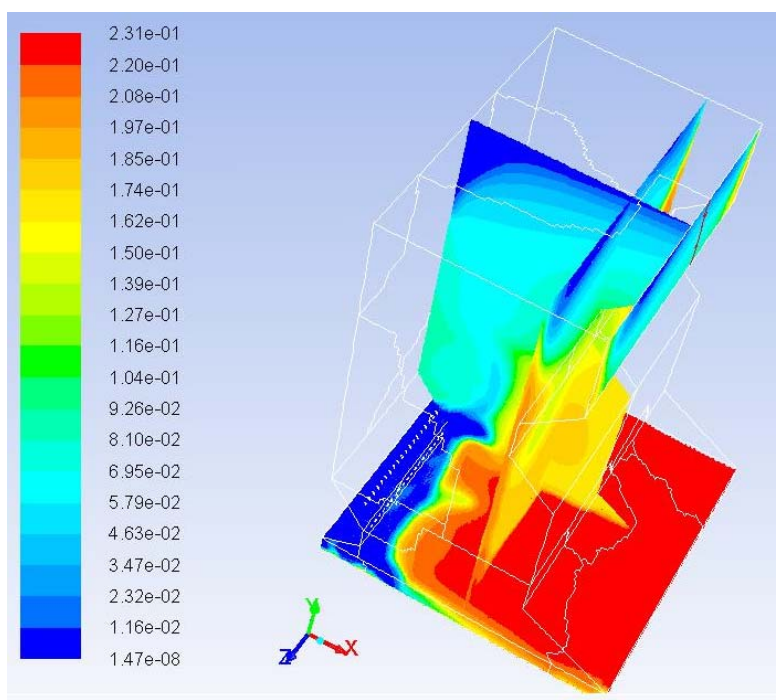

Fig. 4. $\mathrm{O}_{2}$ content in the central planes, over the stoker and in the outlet window plane

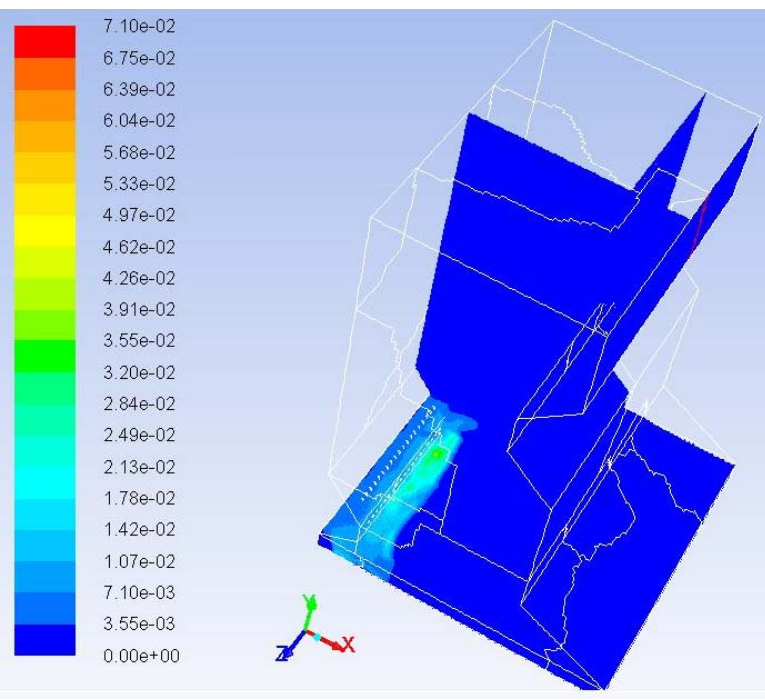

Fig. 5. CO content in the central planes, over the stoker and in the outlet window plane

Fig. 6 presents the content of $\mathrm{CO}_{2}$ in the central planes, over the stoker and in the outlet window plane. In this figure $\mathrm{CO}_{2}$ content as a results of oxidation of $\mathrm{CO}$ was showed. Fig. 7 presents the thermal field in the central planes, over the stoker and in the outlet window plane. On the grate of the boiler temperature was higher than in the region of combustion of coal. The combustion process of volatiles took place upon the grate. The temperature of the flue gas decreased along the height of boilers as a result of heat exchange between the flue gas and waterwalls in the combustion chamber.

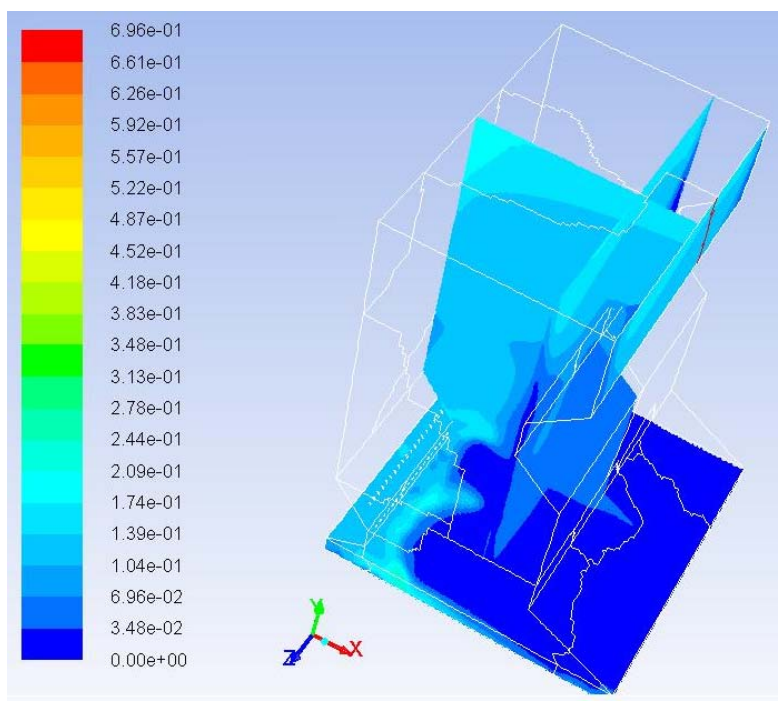

Fig. 6. $\mathrm{CO}_{2}$ content in the central planes, over the stoker and in the outlet window plane

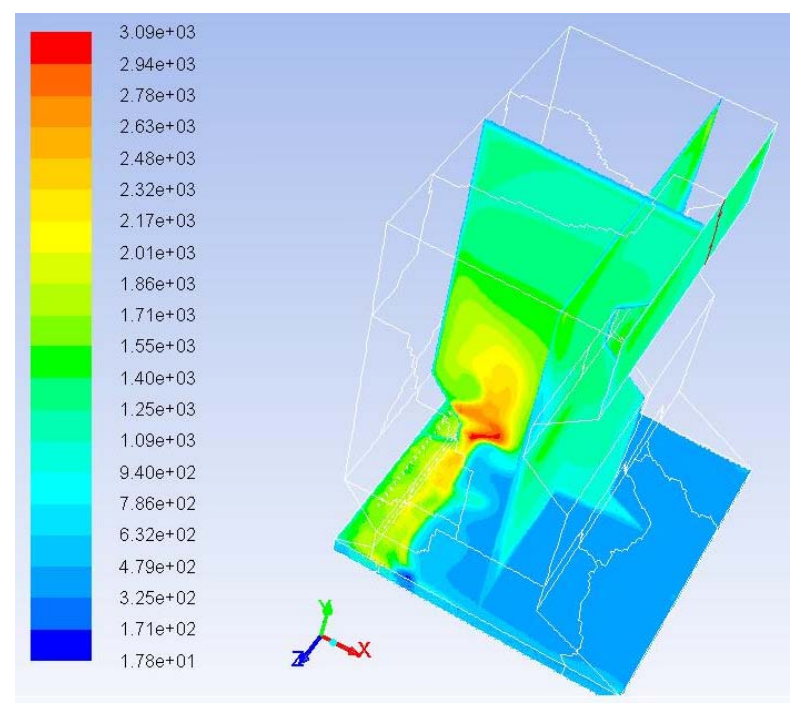

Fig. 7. Thermal field in the central planes, over the stoker and in the outlet window plane

Fig. 8 presents the residence time and the average temperature of coal particles on the stoker. It is very hard to show real data for all particles as a function of the residence time and temperature on the stoker.

Fig. 9 to 12 presents the content of $\mathrm{O}_{2}, \mathrm{CO}, \mathrm{CO}_{2}$ and the thermal field in the outlet window plane. Measurements was made at the outlet from the combustion chamber. The computational 0-dimensional model was taken into account in calculating the temperature of the flue-gas at the outlet from the furnace. Therefore Figures from 9 to 12 show final results obtained from the numerical modelling of the combustion chamber of the WR-40 boilers. 

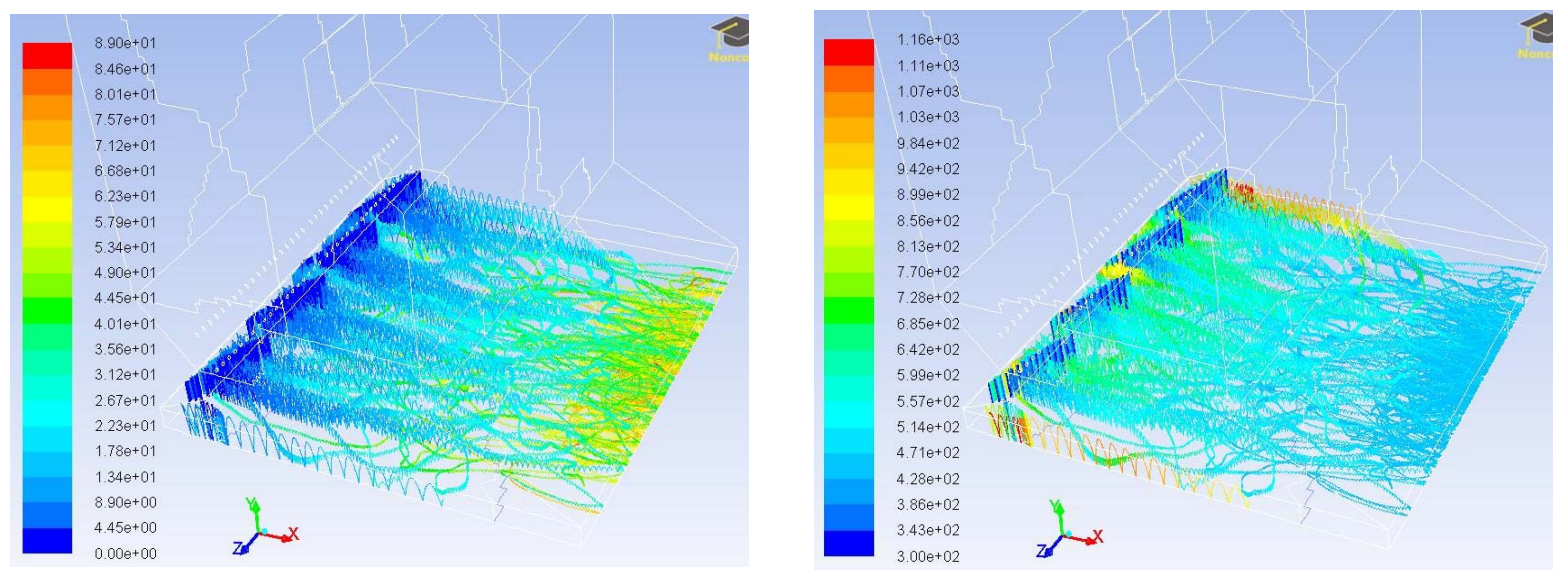

Fig. 8. Residence time and average temperature of coal particles on the stoker

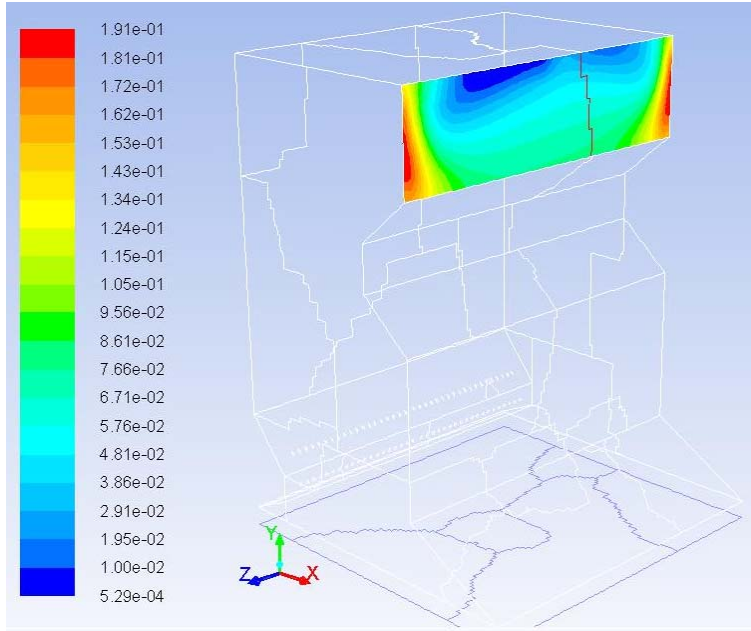

Fig. 9. $\mathrm{O}_{2}$ content in the outlet window plane

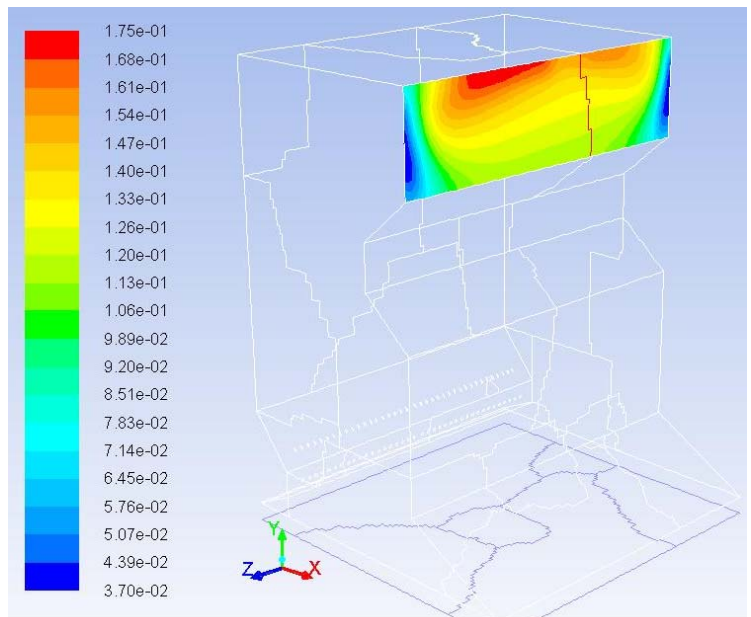

Fig. 11. $\mathrm{CO}_{2}$ content in the outlet window plane

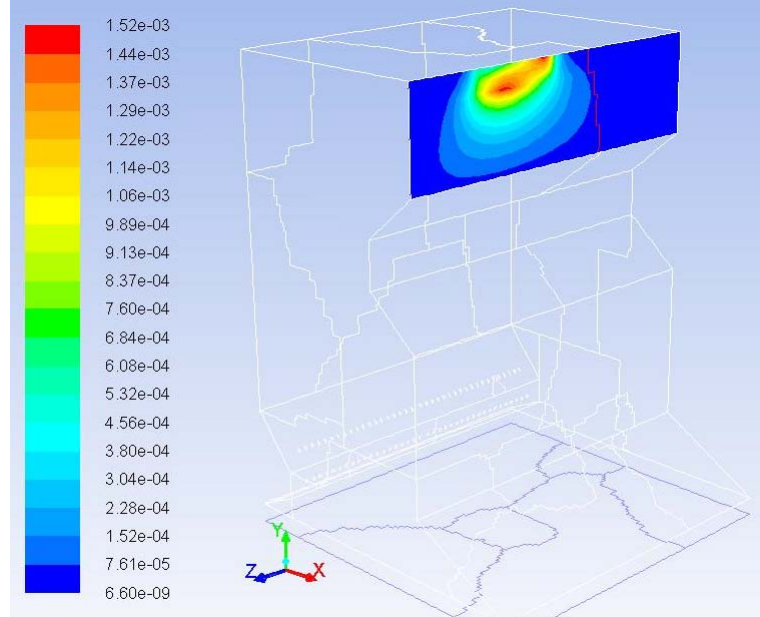

Fig. 10. CO content in the outlet window plane

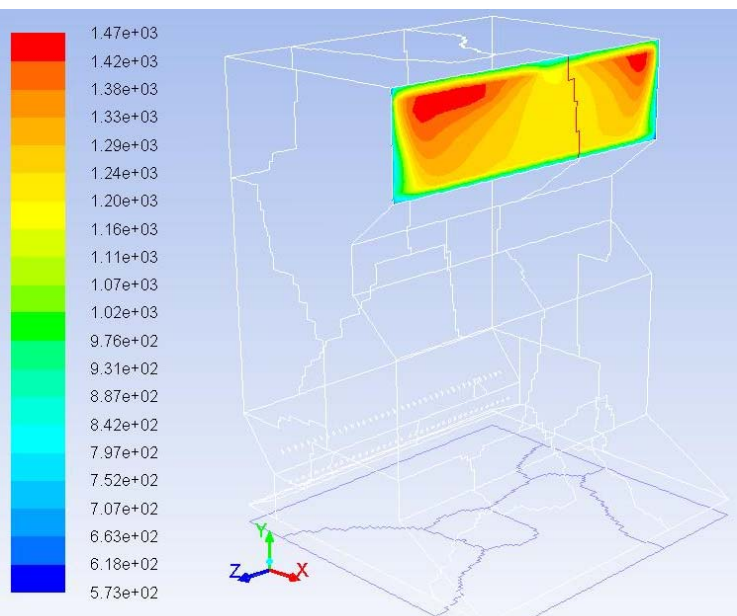

Fig. 12. Thermal field in the outlet window plane 


\section{COMPARISON OF CFD MODELLING WITH ZERO-DIMENSIONAL CODE CALCULATIONS}

In order to obtain the flue gas temperature at the furnace chamber outlet when the outlet window surface area average temperature equals to $982^{\circ} \mathrm{C}$, the same values obtained from the boiler measurements are entered as input data both into the numerical model and into the 0-dimensional model. Variant numerical calculations show that the match of the $t_{k}^{\prime \prime}$ value for both models is achieved if the furnace chamber wall emissivity in the CFD model is assumed at $\varepsilon_{s c}=0.9$. Since in practice it is impossible to measure the emissivity of furnace chamber walls, the verification presented in this paper is a good method of obtaining a numerical model which reflects furnace operating conditions in a reliable way.

In Table 4 the temperature and the concentration values of $\mathrm{O}_{2}, \mathrm{CO}, \mathrm{CO}_{2}$ and $\mathrm{NO}_{\mathrm{x}}$ at the furnace chamber outlet are listed as results obtained from CFD modelling and as results calculated using a zerodimensional code $\left(t_{k}^{\prime \prime}\right)$ and measurements $\left(\mathrm{O}_{2}, \mathrm{CO}, \mathrm{CO}_{2}\right.$ and $\left.\mathrm{NO}_{\mathrm{x}}\right)$. The concentration values of $\mathrm{O}_{2}, \mathrm{CO}$, $\mathrm{CO}_{2}$ and $\mathrm{NO}_{\mathrm{x}}$ at the furnace chamber outlet were achieved by Ultramat 23 analyser.

Table 4. Temperature and concentration values obtained in the CFD and the 0-dimensional model

\begin{tabular}{|c|c|c|c|}
\hline Data & Unit & $\begin{array}{c}\text { Computational } \\
\text { /Measurements }\end{array}$ & CFD Model \\
\hline $\mathrm{O}_{2}$ & $\%$ & 6.8 & 6.85 \\
\hline $\mathrm{CO}$ & $\%$ & 0.0196 & 0.0184 \\
\hline $\mathrm{CO}_{2}$ & $\%$ & 13.21 & 12.24 \\
\hline $\mathrm{NO}_{\mathrm{x}}$ & $\mathrm{ppm}$ & 343.8 & 346.6 \\
\hline$t_{k}^{\prime \prime}$ & ${ }^{\circ} \mathrm{C}$ & 982 & 982 \\
\hline
\end{tabular}

\section{CONCLUSIONS}

- It has been shown that a reliable temperature at the furnace chamber outlet by means of numerical modelling is possible using a 0 -dimensional boiler model based on data obtained from the boiler measurement.

- $\mathrm{O}_{2}, \mathrm{CO}, \mathrm{CO}_{2}$ and $\mathrm{NO}_{\mathrm{x}}$ concentrations at the furnace chamber outlet obtained by means of CFD modelling show a fairly good consistency compared to measured values.

- The information concerning the emissivity of the boiler waterwalls found in this way may be useful in CFD modelling for the most common situation when the flue gas temperature at the furnace chamber outlet is unknown.

Investigations presented in this work were partially financed within the KIC InnoEnergy innovation project on 'Efficient Coal Fired Stoker Boiler (EcoStoker).

\section{SYMBOLS}

A pre-exponential factor

$A^{r} \quad$ ash content as-received state

C1 mass diffusion limited rate constant

C2 kinetics limited rate pre-exponential factor

$C^{r} \quad$ carbon content as-received state, $\%$ 


$\begin{array}{ll}E & \text { activation energy, } \mathrm{J} / \mathrm{kmol} \\ E A & \text { kinetics limited rate activation energy, } \mathrm{J} / \mathrm{kmol} \\ H^{r} & \text { hydrogen content as-received state, } \% \\ N^{r} & \text { nitrogen content as-received state, } \% \\ O^{r} & \text { oxygen content as-received state, } \% \\ Q^{r} & \text { coal lower calorific value as-received state, } \mathrm{kJ} / \mathrm{kg} \\ S^{r} & \text { sulphur content as-received state, } \% \\ W_{t}^{\prime} & \text { moisture content as-received state, } \% \\ k & \text { coefficient obtained based on coal compositions } \\ l & \text { coefficient obtained based on coal compositions } \\ m & \text { coefficient obtained based on coal compositions } \\ n & \text { coefficient obtained based on coal compositions } \\ t_{k}^{\prime \prime} & \text { average temperature of flue gases at the furnace outlet, }{ }^{\circ} \mathrm{C}\end{array}$

\section{REFERENCES}

Ansys Fluent. Computational Fluid Dynamics, Ansys Inc., England.

Asotani T., Yamashita T., Tominaga H., Uesugi Y., Itaya Y., Mori S., 2008. Prediction of ignition behavior in a tangentially fired pulverized coal boiler using CFD. Fuel, 87, 482-490. DOI:10.1016/j.fuel.2007.04.018.

Dal-Secco S., Hernik B., Pronobis M., Wejkowski R., 2007. Simulations of protection air system in front wall fired boiler OP650 in Rybnik Power Plant. Arch. Combust., 2007, 27, 9-18.

Eaton A.M., Smoot L.D., Hill S.C., Eatough C.N., 1999. Components, formulations, solutions, evaluation, and application of comprehensive combustion models. Prog. Energy Combust. Sci., 25, 387-436. DOI: $10.1016 / \mathrm{S} 0360-1285(99) 00008-8$.

He B., Zhu L., Wang J., Liu S., Liu B., Cui Y., Wang L., Wie G. 2007. Computational fluid dynamics based retrofits to reheater panel overheating of No. 3 boiler of Dagang Power Plant. Computers Fluids, 2007, 36, 435444. DOI: 10.1016/j.compfluid.2005.09.005.

Hernik B., 2012. Numerical modeling of BP 1150 boiler by commercial numerical code. J. Power Technol., 2012, 92, 34-47.

Hernik B., Pronobis M., 2012a. A zero-dimensional model used as a basis for numerical modelling of OP-650 boiler. Arch. Energ., 42, 17-26.

Hernik B., Pronobis M., 2012b. Verification of the boiler numerical model with a zero-dimensional model, In: G. Stepan (Ed.), Proceedings of the Eight International Conference on Mechanical Engineering, Budapest, Hungary, May 24-25, 2012, 612-623.

Kær S.K., Rosendahl L., Baxter L.L., 2006. Towards a CFD-based mechanistic deposit formation model for straw-fired boilers. Fuel, 85, 833-848. DOI: 10.1016/j.fuel.2005.08.016.

Scharler R., Obernberger I., 2000. Numerical modelling of biomass grate furnaces. In: Proceedings of the Fifth European Conference on Industrials Furnaces and Boilers, Rio Tinto, Portugal, April 2000.

Williams A., Backreedy R., Habib R., Jones J.M., Pourkashanian M., 2002. Modelling coal combustion: The current position. Fuel, 81, 605-618. DOI: 10.1016/S0016-2361(01)00158-2.

Yin Ch., Rosendahl L., Kær S.K., Clausen S., Hvid S.L., Hille T., 2008. Mathematical modeling and experimental study of biomass combustion in a thermal 108 MW grate-fired boiler. Energy Fuels, 22, 1380-1390. DOI: 10.1021/ef700689r. 